\title{
Indonesian Interests in Bali Democracy Forum (BDF)
}

\author{
Wilyam Lie ${ }^{1}$, Muhnizar Siagian ${ }^{2}$ \\ ${ }^{1}$ Student of International Relations Department, Sebelas Maret University, Perum Puri Tama Indah, Purbalingga, \\ Indonesia \\ ${ }^{2}$ Lecturer of International Relations Department, Sebelas Maret University, Bengkulu, Indonesia \\ \{wilyamseal, muhnizar.siagian\}@gmail.com
}

Keywords: Developmentalism, Diplomacy, Democracy, Bali Democracy Forum

\begin{abstract}
The end of the Cold War is marked by the changes of issues related with the dynamics of the international political constellation. The urgency of traditional issues such as the military, have begun to change to nontraditional issues such as humanity, environment, and democracy. The existence of these issues will certainly become an attention to foreign policy of a country that run with the diplomacy activities, so the country should adapt and focus more on non-traditional issues. Democracy today is understood as one aspect to show the image of the nation. In diplomatic activity, the image of a democratic country plays an important role in order to achieve the goals of the diplomacy and Indonesia itself embarked on a democratic diplomacy activity in the ideas of the implementation Bali Democracy Forum. This study attempts to examine Indonesia's national interest in developmentalism as a third world country in diplomatic activities at Bali Democracy Forum.
\end{abstract}

\section{INTRODUCTION}

Democracy in the modern era has begun to become a major concern for the third world countries. This happened due to the global demands on the dissemination of democracy, protection of human rights, declining capacity of the environment, and the resolution of communal conflict (Perwita, 2009). Democratization demands in countries that still implemented as autocracy or semi-democracy system to become a full democracy nation is the main focus of international forums and agenda, such as United Nations forum and regional democracy forums. The urgency of democracy now emerged as a result of the end of the Cold War, where nontraditional issues began to be looked deeply and thoroughly.

Modern democracy which is a global demand, closely related to the diplomacy that wrapped in it. Democracy often to be used as diplomacy images by the third world countries that related with the fulfilment of national interest. The third world countries that do not yet have traditional powers in international politics use democracy as a support system of political and economic power in the international arena. With the state interest, it makes democracy and diplomacy become complementary that is crucial for third world countries

In the period between 1974 and 1990, there were at least 30 countries that made the transition to a democratic system, which in this era referred to "Global Democratic Revolution" (Huntington, 1991). In its development, no one can calculate and provide an indicator of why the democratization from the third wave emerged in the 1970s to the 1990s, but Huntington (1991) describes five major points that contribute significantly to the emergence of the third wave of democratization.

The deepening problems
concerning the legitimacy of the
authoritarian regime in the global order,
where the values of democracy are widely
more acceptable. It happened because of
the consequences of the authoritarian
regime itself often fails to maintain the
"Performance Legitimacy" in the economic
and military sectors.

- The substantial increase in global economic growth in the 1960s, where there was an improvement in quality of life, the quality and educational levels, 
and the raising of middle-class people in many countries.

- Striking transformation in the doctrine and activity of the Catholic Church as the manifestation of Second Vatican Council in 1963 to 1965 and the national transformation of the Catholic Church from authoritarian supporter to the opposite of the authoritarian.

- The changes of external actors from international politics in policy influence activities, in this case more dominated by the European community, the United States, and the Soviet Union.

- The emergence of snowball effects where the demonstration effects of the democratic transition at the beginning of the third wave stimulate other countries to make the transition to democracy.

Indonesia experienced in a phase of dictatorship under President Soeharto during the New Order era from 1967 until 1998. The existence of democratic limitations in Indonesia caused egalitarian patterns in Indonesia became feudalist (Purnaweni, 2004). It can be seen through the unification of bureaucracy and the military under one command, the simplification of the political party, the injustice of the general election, and the emergence of anticriticism aimed solely for the sake of national stability. The New Order period is also identic with human rights violation cases and the environment cases such as the mysterious shootings (1981-1985), Tanjung Priok (1984-1987), Trisakti (1998), and human rights violations in East Timor (1999). These cases caused in the implementation of US embargo sanction to Indonesia. In order to eradicate the issues, the government is untouchable by the national law because they have an absolute immunity. The issues of democratization of the government also did not escape by the study of the New Order regime, where in order to achieve economic stability, leaders of a country are endeavoured not to keep changing. Through the Five Year Development Plan (Repelita), President Soeharto could continue his rule in Indonesia.

In its development, Indonesia ended three decades of dictatorship of the Soeharto regime and then held democratic elections in 2004 and it became the third largest wave of democratic transition in Southeast Asia (Shin, 2008). Demonstration of Indonesia's democratic transition from an authoritarian regime to democracy have snowball effects in other Southeast Asian countries, as evidenced by the adoption of democratic values within the constitution of Thailand and Cambodia (Shin, 2008).

\section{METHODS}

This paper used explanatory qualitative methods because of this methods needs an existing theory to be applied and analyse between two objects (Elman, 2005). Developmentalism theories was chosen because it shows similarity with the topics and also this topic is located in third world countries. The purpose of this methods is to discover and trying to explain the relations of Indonesia and Bali Democracy Forums (Elman,2005).

\subsection{DEVELOPMENTALISM}

Developmentalism can be simply interpreted as a similarity or chemistry that occurs between the interests of industrialized countries with the political elite of third world countries (Rahardjo, 2012). Developmentalism can be regarded as a theory of economics that embraced by third world countries in order to achieve their national interest, especially in economic development. Developmentalism appears as the main reason why third world countries are willing to make a democratic transition. Seeing from its history, after the Cold War in 1991, the United States with its liberalism ideology coming out as a winner, America became the only superpower that capable to set up the global order system in such a way with a tendency for the United States to continue to do hegemony in ideology.

The ideology of American liberalism and hegemony in the economic sector creates an opportunity for third world countries to work together and achieve their national interests. In addition, the ideology of liberalism with the democratic values is considered to be the most suitable for countries in almost all the world. Thus, using democracy as a diplomacy image based on the idea of developmentalism becomes inevitable.

There is a strong relation between developmentalism, democracy, and foreign investment. By continuously attempting to transiting democracy from the old order to the new order, Indonesia tries to adapt to a new era of the international association that lays democracy with its indicators as the most important issue. The state will be considered as an adaptable and progressive country if they are able to follow the rapid changes of the world, which is important for Indonesia capital. Behind all of that Indonesia certainly can 
access a variety of foreign investment that is needed in the development period.

\section{RESULT AND DISCUSSIONS}

Bali Democracy Forum (BDF) is a dialogue forum among nations on democracy. BDF was established by the Indonesian government in 2008 as cooperation in developing democracy as well as a platform to promote democracy and peace as the solution and prevention of inter-state conflict (Ministry of Foreign Affairs of the Republic of Indonesia, 2010). At the beginning of the 2-days meeting in Bali from 10-11th December 2008, this forum was attended by 32 Representatives of AsiaPacific countries as delegates and 8 representatives of European countries and the United States as observers (Institute for Peace and Democracy, 2008). BDF I, which holds the theme "Building and Consolidating Democracy: A Strategic Agenda for Asia" has main objective to build and consolidate democratic values after the 1997 financial crisis that hit in several countries in the Asian continent. Until now, BDF has been conducted as many as 10 meetings since 2008 until 2017 with the increment of the number of delegates and the complexity of the dynamics discussion. In the process of development, BDF always holds different themes and with different meanings. Starting from Global Governance, Economic Development, Pluralistic Society, until criticize whether the values of democracy that has been echoed was conveyed yet or not. This can be a reflection that Indonesia, which had a red note on humanitarian issues, is now struggling to become more democratic and civilized in which a democratic and civilized country will have more place among the modern countries in the world.

BDF was spearheaded by Indonesia who at that time believed that democracy cannot be imposed from outside and by outsiders (Sutiono, 2009). Basically, in order to make democracy going well, it needs a strong root among democratic life. It can be seen by the President SBY's opening speech in first BDF meeting,

"And along the way, we learned many things. We learned that in the wake of every challenge we faced-be it terrorism, ethnic conflicts or economic crisis -our response, our instinct has always been to strengthen, not lessen, democracy-what we would call a "democratic response" (Institute for Peace and Democracy, 2008).
It is very difficult for a country to imitate the model of other country politics without any further study of the social and political conditions. Therefore, the BDF is not only as a mutually patronizing and coercive forum, but also as a forum for dialogue and cooperation in the practice of democracy through a relevant approach. Since the establishment of BDF, Indonesia can increase their ranking of democracy parameter from 110th in 2002 to become 60th in 2010 (Economist Intelligence Unit, 2010). It can be concluded that the foreign policy and the establishment of BDF by the SBY'S era has giving the best results for Indonesian democracy.

The establishment of BDF by Indonesian government in 2008 has relations with idiosyncrasies or the subjective factor in decisionmaking. President Susilo Bambang Yudhoyono (SBY), who has a background from the military world, has more of orderliness (ceremonial and protocol) and reputation (position and respect). It is clear from the foreign politics during his leadership era that high profile outward looking with the jargon of "zero enemy thousand friends" in order to achieve Indonesia's national interests was prioritized (Situmorang, 2015). BDF is one of the arenas where Indonesia in the era of SBY wanted a recovery from bad record of Indonesia's image during the New Order era, and made Indonesia can bargain and attract sympathy from modern industrial countries such as the United States and the European Union and also sympathy of countries the third world which is manifested by the statement of neutrality and putting humanity as urgent issues. BDF has succeeded in improving Indonesia's investment reform climate such as strategic partnership and changing the view of modern industrial countries towards Indonesia (Saputra, 2013). Indonesia has begun to get a positive response from the international world, which is considered to affect the development and national resilience and domestic stability in the future.

On $7^{\text {th }}$ December 2017, the 10th meeting of BDF with the theme "Does Democracy Deliver?" was held. It became a major concern when the elected President, Joko Widodo, had an indication of lack of focus on the BDF. Unlike the era of President SBY who is very active in BDF, President Joko Widodo seems not concerned about BDF. At the 9th BDF meeting, President Joko Widodo made a late confirmation of his presence on the democracy forum, whereas the time span to be held was less than a month (Dharma, 2016). Besides, at the 10th BDF forum meeting in Banten, instead of President 
Jokowi deliver his speech and open the forum directly and officially, the opening ceremony was through the elected vice-president Jusuf Kalla (Ministry of Foreign Affairs of the Republic of Indonesia, 2017).

Judging from the analysis of Idiosinkretism, President Joko Widodo has a slightly different view from SBY on BDF matters, President Joko Widodo who has a simple and honest nature prefer inwardlooking and low profile and he is more concerned about cooperation that can produce concrete benefits compared only produce an image because basically since the era of leadership of President SBY, Indonesia has begun to succeed for the image itself as a democratic and civilized country (Situmorang, 2015).

Differing views on the level of importance of the BDF by the two Indonesian leaders illustrate that has various need for the output of diplomacy. Basically, president SBY who has high profile prioritizes Indonesia's diplomacy output as a force to build political power and good image in the international arena, while president Joko Widodo prefers the output of Indonesian diplomacy as something concrete and can be realized and displayed more than just power politics and good image of the nation, in fact, the image of Indonesian democracy has been formed quite well in the era of President SBY since the attention of Indonesia in international forums was improved.

Nevertheless, the main concern in the BDF agenda itself is the relations between democracy, security and stability. Taking learns from Indonesia's history, democracy is an essential path for a better and open system of national life. Democracy should be presented for supporting the government and the benefit of the people and the country. Democracy must unite, not separate in terms of cooperation for prosperity and peace that can be achieved if stability is available.

\subsection{DEMOCRACY AS A COMMODITY OF DIPLOMACY THROUGH BALI DEMOCRACY FORUM}

\subsubsection{History of Democracy Issues}

The turning point in the development of hard power diplomacy and soft power diplomacy was at the end of the Cold War in 1991, the issues during the Cold War was focused more on the state-centre by prioritizing realism as a benchmark in calculating the power of a country. This could be happened because, during the Cold War, there is not enough room to discuss non-traditional issues such as human rights, gender, and the environment. Whereas in the post-Cold War, the emerging of issues is more complex than just traditional issues of realism, which at this time began to emerge criticism of humanism, environment, and democratization.

The history of democracy in Indonesia was covered by red notes in democracy things. In postIndonesian independence, there has been no emphasis on non-traditional issues, because after the independence Indonesia still falls into the context of the Cold War. In its development of the new Order period, Indonesia has not yet focused on nontraditional issues, whereas the international politic has begun to glance at non-traditional issues because the Cold War was over in 1991 which marked by the collapse of the Soviet Union. Violation of democratic values conducted by Indonesia both outside and inside the country often become major concern of the international community. As an example of the Indonesian human rights abuses committed in East Timor in 1991, the shooting in Santa Cruz by the Indonesian military (Arifianto \& Zulkarnain, 2016). The case of Santa Cruz which is conducted by Indonesia has been criticized from the world society and international organizations, even the United States began to implement economic and military embargo to Indonesia because the Indonesian government is considered failed in applying their foreign policy. In the New Order era, there were also cases of Tanjung Priuk and many mysterious disappearances to activists who criticized Suharto's authoritarian rule. Aceh and Papua are also listed as military operations that violate many of human rights and democratic values.

Reflecting on the embargo experience done by the United States, it makes Indonesia's democratic transition growing up. This is marked by slow reforms of government such as the 1998 reforms that transformed the Indonesian authoritarian image into a transitional image of democracy. The peak of Indonesia's democratization occurred during the era of President Susilo Bambang Yudhoyono. Indonesia began to focus on the good image of democracy wherein the era of the previous president, Indonesia tended to see less democracy as a domestic urgency. In SBY's presidency, Indonesia which considered survived on the democratic transition within a country, wants to become the initiator of a forum which will be functioned as a forum of democracy dialogue among nations, and began to initiate the 
establishment of BDF in 2008 in the era of President SBY. BDF is a feature of Indonesian foreign policy, where Indonesia wants an improvement over the red value of Indonesia's enforcement of human rights and democratic issues that had once experienced dark period of New Order era in 1967-1998, because basically the image of a democratic country will provide more political and economic benefits than the image of an authoritarian country.

This is not apart away from the foreign policy jargon of SBY "zero enemy, thousand friends" which greatly eliminates the enemy. He argues that the enemy will cause instability and disrupt the economic development and investment that is being run by him to bring Indonesia out from the economic crisis in the post-New Order era. In addition, according to Mangadar Situmorang, SBY has an outward-looking view and makes his own arena for Indonesian Foreign Policy maneuvre. This is important because Indonesia needs fresh funding from various parties to run post-crisis development in 1998.

\subsubsection{Developmentalism and the Development of Democracy as the Image of Diplomacy}

Diplomacy is a country's effort to achieve its national interests. Diplomacy is a major weapon of the country in relations with the international world. A country with a relatively large bargaining power or bargaining position will be easier to achieve their interests. The diplomatic issues used by the state always follow the dynamics of the international political constellation, where initially countries tend to use hard-power diplomacy as the main road to the fulfilment of national interests. States now have become more focused on soft-power diplomacy to fulfil their national interests by using non-traditional forces such as culture, education, and strategic partnership (Nye, 2004).

The implications of third world countries including Indonesia on democracy as a commodity of diplomacy are the evident through BDF. BDF is also observed by the industrial countries, serves as shells of third world countries to show off democracy in order to attract sympathy from nonmember countries of BDF. In line with developmentalism, the existence of BDF will make for third world countries easier to get help from industrialized countries like the United States. In this case, the power indicator of the US influences the national development of third world countries. It can be measured by how democratic they are. The more cooperation third world countries involved, the more they apply and adapt to democracy.

Indonesia after the reformation in 2000, experienced a significant increase in foreign investment level, it is certainly not far away from the social and political conditions of Indonesia that have begun to stabilize after the financial crisis that hit Asia in 1997. In addition, the activeness of Indonesian diplomacy in international arena affects the amount of investment in Indonesia. Therefore, in 2010 Indonesia was able to increase the investment growth an average of $33 \%$ of total GDP (Bank of Australia, 2011).

Indonesia as country is still struggling to develop in a mid of international politic dynamic because of the some domestic conditions. Reflecting on history, the poor quality of democracy in Indonesia is not only destabilizing Indonesia's position in the international arena but also disrupting the social and political situation in the country. Although Indonesia is known as the largest Muslim population in the world and supported by its hospitality (Acharya, 2014), it does not mean that democratic transition in Indonesia is running smoothly.

Indonesia is now able to adjust the demands of the international world, one of which is a democracy on the major achievements is establishing BDF. Indonesia is not a country with high bargaining position when viewed from its military and economic capacity (Trihartono, 2016), with that inevitably, Indonesia should be able to cooperate and make good relations with the partners, and one of them is United States and western countries which is very pro against democratic values. As an initiator of the BDF, Indonesia has attracted the western countries. In the end, the better quality of Indonesian democracy is used to form a positive image of Indonesia which previously received much criticism, especially in the New Order and the transition to reform.

Although Indonesia has different focus and perspective towards BDF in accordance with the president who served, then it is not solely make BDF is no longer important for Indonesia. Analysed through developmentalism, third world countries including Indonesia, will not cease to cooperate with modern industrialized countries if the chemistry of interests on both sides still remains. In this case, $\mathrm{BDF}$ is a suitable arena for Indonesia to make democracy as an image to achieve Indonesia's national interests. Since democracy is crucial after the post-Cold War, Indonesia's involvement in democracy forums, especially after Indonesia become an initiator of a democratic forum, is 
indispensable to the national interests. This can be happened because Indonesia still dependent on foreign investment, domestic stability, economic growth, and strategic nuance where one way to fulfil this dependency is to implemented the main indicators of partner countries in this case is the United States and Western countries with its liberal democracy. Indonesia still needs support from industrial countries in the form of political and economic power, which is why Indonesia considered continuing to maintain $\mathrm{BDF}$ as a counterweight to national and international stability. Indonesia itself has proven the efficacy of this democracy forum as a good image-forming arena. Also Indonesia can get US \$ 160 million US for the national development on education assistance and other cooperation in security, economy and investment, democracy and climate change anticipation (Sherlita, 2010).

\section{CONCLUSION}

In conclusion, BDF is a forum initiated by Indonesia as well as Indonesia as a permanent host to form a better image in the field of democratic values. Indonesia's better image in democracy is the entrance of Indonesia to associate with prodeveloped countries toward democratic values. The image is used for the national interests of Indonesia to access various assistances to continue the era of developmentalism which is still being pursued since the SBY's government.

\section{REFERENCES}

Arifianto, A., \& Zulkarnain. (2016, November 10). Dampak Insiden Santa Cruz Tahun 1991 Di Timor Timur Terhadap Kejasama Militer Indonesia-Amerika Serikat Tahun 1992-1995. Yogyakarta, Yogyakarta, Indonesia.

Bank of Australia. (2011, December). The Growth and Development of the Indonesian Economy. Retrieved from RBA: https://www.rba.gov.au/publications/bulletin/201 1/dec/pdf/bu-1211-4.pdf

Dharma, S. (2016, November 29). Belum Pasti Datangi Bali Democracy Forum 2016, Perhatian Jokowi DIpertanyakan. Retrieved from okezone: https://news.okezone.com/read/2016/11/29/18/155421 6/belum-pasti-datangi-bali-democracy-forum-2016perhatian-jokowi-dipertanyakan

Huntington, S. P. (1991). Democracy's Third Wave. Journal of Democracy, 12.
Institute for Peace and Democracy. (2008). Speeches and Proceeedings Bali Democracy Forum. Jakarta: Department of Foreign Affairs Republic Indonesia and Institute for Peace and Democracy.

Kementerian Luar Negeri Republik Indonesia. (2010, October 7). Bali Democracy Forum. Retrieved from kemlu: https://www.kemlu.go.id/id/lembarinformasi/Pages/Bali-Democracy-Forum.aspx

Kementerian Luar Negeri Republik Indonesia. (2017, Desember 7). Wakil Presiden Jusuf Kalla Resmi Buka Bali Democracy Forum ke-10. Retrieved from kemlu: https://www.kemlu.go.id/id/berita/beritaperwakilan/Pages/Wakil-Presiden-RI-Resmi-BukaBali-Democracy-Forum-ke-10.aspx

Nye, J. S. (2004). Soft Power The means To Success in World Politics. New York: PublicAffairs.

Perwita, A. A. (2009). Demokrasi dan Politik Luar Negeri Bebas Aktif. Jurnal Diplomasi, 8.

Purnaweni, H. (2004). Demokrasi Indonesia: Dari Masa Ke Masa. Jurnal Administrasi Publik Unpar, 121.

Rahardjo, M. D. (2012). Pembangunan Pasca Modernis Esai-Esai Ekonomi Politik. Yogyakarta: Diandra Primamitra.

Saputra, A. B. (2013, Januari 03). Politik Luar Negeri Indonesia Dibawah Susilo Bambang Yudhoyono Tahun 2009-2011. Retrieved from repository unri: https://repository.unri.ac.id/bitstream/handle/1234567 89/1066/PLN\%20RI\%20Era\%20Presiden\%20SBY\%2 02009-2011.pdf?sequence $=1 \&$ is Allowed $=y$

Sherlita, W. (2010, November 09). Kemitraan Strategis AS_Indonesia Resmi Diluncurkan. Retrieved from VOA: https://www.voaindonesia.com/a/kemitraanstrategis-as-indonesia-resmi-diluncurkan-106997018/85818.html

Shin, D. C. (2008). The Third Wave in East Asia: Comparative and Dynamic Perspectives. Taiwan Journal of Democracy, 4.

Situmorang, M. (2015). Orientasi Kebijakan Politik Luar Negeri Indonesia di Bawah pemerintahan Jokowi-JK. Jurnal Ilmiah Hubungan Internasional, 68.

Sutiono, P. (2009). The Bali Democracy Forum and the Need For Home-Grown Democracy. Jurnal Diplomasi, 85-86.

Economist Intelligence Unit. (2010). Democracy Index 2010. The Economist Intelligence Unit 